\title{
北上川における津波の河川遡上と津波汇濫流 解析から導かれる現地観測データの解䣋 DISUCUSSION ABOUT OBSERVED DATA BASED ON THE SIMULATION OF TSUNAMI RUN-UP AND INUNDATION IN THE KITAKAMI RIVER
}

\author{
松井大生 1 ・内田龍彦 2 ・福岡捷二 3 \\ Daiki MATSUI, Tatsuhiko UCHIDA and Shoji FUKUOKA \\ 1学生会員 中央大学大学院 理工学研究科都市環境学専攻（干112-8551 東京都文京区春日1-13-27） \\ 2正会員 博(工) 中央大学研究開発機構教授（同上） \\ 3フェロー 工博 Ph. D. 中央大学研究開発機構教授（同上）
}

\begin{abstract}
There are two major factors which make it difficult to simulate tsunami run-up in the Kitakami River by the 2011 Tohoku Earthquake. Since the water level gauges in the bay or estuary broke due to the huge tsunami, inflow volumes from the ocean and tsunami waves could not be estimated. And, the water running up in the river flowed out to the inundation area not only by overflowing but also levee breaches. It is considered that these flows have significant effects on the behavior of tsunami run-up in the river.

This study aims to discuss the observed data based on the simulation of the tsunami run-up and inundation in the Kitakami River. First, we conducted the simulations using two fault models and discussed the reproducibility, particularly of the inflow conditions of the tsunami. Second, we investigated the simulations with and without levee breaches. Through comparisons between the simulations and observation results, the effects of levee breaches on the tsunami were discussed.
\end{abstract}

Key Words : tsunami, run up in rivers, the Kitakami River, inundation, fault model, levee breach, non-hydrostatic quasi-3D model, 2011 Tohoku Earthquake

\section{1. 序論}

2011年3月11日に発生した東北地方太平洋沖地震に伴 う津波（以下では今次津波と呼ぶ）は，河川を遡上する 津波が堤防越流や破堤汇監することにより，沿岸域のみ ならず海岸から離れた沿川地域にも大きな被害をもたら した．海域から伝播してきた津波がどのように河川遡上 し，汇濫をするのか，また，その相互作用を理解するこ とは防災詨策を講じる上で重要である。このためには, 津波の伝播から河川遡上，汇濫流を一体的に再現できる 実用的な数值解析法による再現計算結果と，現地観測 データとを合わせて検討し，今次津波で生じた現象を解 明することが求められる.

著者ら ${ }^{11}$ は，水深積分モデルの枠組みで流速と圧力の 鉛直分布を考慮できる一般底面流速解析法2)を，津波解 析に応用した「非静水圧準三次元津波解析法」を開発し てきた. 水位が時空間的に密に計測された北上川の津波 河川遡上実験3) と比較し, 解析結果は各点の水位と河口
部の流速の時間変化を再現したことから，境界条件が適 切に与えられた場合においては，この解析法は河川の津 波遡上現象を適切に再現できることがわかった。しかし， 北上川の今次津波の再現計算では，全体的に水位が高く 見積もられており，この原因を究明し，再現性を向上さ せることが課題として残されていた。

今次津波の再現計算を扱った既往研究の中で，河川遡 上を主眼とした研究例は多くない，津波波高が低く，水 位が縦断的に密に観測されている利根川では，赤穂・石 川4)や二階堂ら5)が検討を行っている. 前者は河口付近 での第一波の最高水位が観測結果に合うように断層モデ ルの変位量を増加させ，後者は河口での実測水位波形の 変位量を引き伸ばして与えることによって，概ね計算結 果は河道内の実測波形を再現している。しかし，津波遡 上が顕著であった東北地方の河川を対象とした，河川遡 上と氾濫流を合わせた検討はほとんど行われていない.

津波遡上実験の解析 3 や既往の利根川の津波遡上解析 4)，5) と比較して，北上川の津波解析を難しくさせている 主要因は二つ考えられる.一つ目は，湾内や河口部での 
水位データが激しい津波によって久測していることによ り，海域から流入する津波の遡上量や波形を検証できな い点である. このため, これを決定づける断層モデルの 選択は重要である. 小園ら6) は国内で多く用いられてい る今次津波の断層モデルである藤井・佐竹モデルと東北 大学モデルの様々なバージョンを用いて, 東京湾内の実 測水位波形と計算結果の比較から再現性と有用性を検討 している．計算結果と実測值の差に比べて，各断層モデ ルでの計算結果の差は小さいように見える.しかし，波 源域から近く，かつ，大きな津波波高が湾に進入し河川 遡上する北上川において，断層モデルによる再現精度の 差を知ることは重要である. 二つ目は, 津波の河川遡上 に伴う河道から堤内地一の氾濫流である. 特に北上川で は，大きな津波波高による越流だけでなく，右岸 $4.1 \mathrm{~km}$ 〜 4.6kmで大規模な破堤が生じており，その規模の大き さから津波遡上に及ぼす影響は小さくないと考えられる。 そこで本研究では，今次津波の波源域での条件を与え る二つの断層モデル, 河川を遡上する津波の解析に適切 と考えられる「非静水圧準三次元津波解析法」と現地に おいて取得された様々なデータを用い, 複数の条件下で 北上川の今次津波解析を行う。さらに, 計算結果と現地 観測データを相互に検証し，考察することで，今次津波 で生じた現象を明らかにし，現地観測データのもつ意味 や役割を理解することを目的とする．まず，第一に，津 波河川遡上解析の再現性の検証を目的として, 東北大学 モデル(version1.2)7) と藤井・佐竹モデル(version4.2) ${ }^{8)}$ の二 つの断層モデルよりそれぞれ求めた初期水位を用いた再 現計算を行う。その比較から今次津波の再現性，特に海 域から流入する津波の波形と遡上量について検討寸る. 第二に，実際に大規模な破堤が生じた北上川右岸 $4.1 \mathrm{~km}$ 〜4.6kmの破堤を考慮した計算を行う. 破堤の考慮の有 無が再現性にどのように影響するのか，また，河道内の 津波遡上や汇濫に及ぼす破堤の影響について検討し，現 地観測データと合わせて考察する.

\section{2. 非静水圧準三次元津波解析法の必要性}

今㳄津波に代表される最大レベルの津波は，湾域や河 口部において波の変形や地形による複雑な流れを生じる。 さらに，その津波が河川を遡上し，堤防越流や破堤を伴 う三次元流れを介して, 汇濫流と相互作用した結果とし て, 構造物や堤防の被災, 局所洗掘一と繋がる. 個々の 現象が広域から局所の様々なスケールを有して相互作用 しており，また，全体のスケールが大きなことに比べ， 構造物周辺等の被災に繋がるような現象は局所的であり, 三次元性を有寸る現象である，そのことから，局所的な 範囲に高精度なモデルを適用寸ることでは, 効果的な防 災対策を検討することは難しいと考えられる. そこで, 流れの三次元性を考慮でき，種々の現象を一体的に再現
できる本解析法を用いる必要がある.

本研究で用いる非静水圧準三次元津波解析法の概要を 示寸. 本解析法は, 水深積分モデルの枠組みで流速と圧 力の鋁直分布を考慮できる準三次元解析法である. 水深 と水深平均流速場は水深積分した連続式と流速と圧力の 鉛直分布を考慮した水深積分した水平方向の運動方程式 により解かれる．レイノルズ応力は渦動粘性係数 $v_{t}$ を用 いて表現し， $v_{t}$ は流速鈖直分布の変形による乱れ生産を 考慮した水深積分乱れエネルギー輸送方程式を用いた 1 方程式モデルにより計算する.

流速と圧力の鉛直分布を計算するため，水深積分した 連続式，水深積分した水平方向の運動方程式と連立して， 渦度の定義式を水深積分した底面流速方程式，水深積分 した渦度方程式，水表面の水平方向運動方程式，二重水 深積分した連続式及び水深積分した鉛直方向運動方程式 を解く．これらの方程式群が流速と圧力の鉛直分布を介 して解かれることにより, 流れの三次元性を考慮した解 析が平面二次元解析の枠組みで可能となる.

これを水面の時空間変化の大きい津波解析に応用する ため，水深積分した鉛直方向運動方程式において鉛直方 向の非定常項を考慮し, 水表面の水平方向運動方程式に おいて，水面における鉛直方向運動方程式を用い水面の 鉛直方向圧力勾配項を考慮している．解析法の詳細と実 験結果との比較については, 文献1を参照されたい.

\section{3. 北上川の津波遡上と汇濫流の一体解析}

\section{（1）検討方法と解析条件}

内田・福岡による既往の研究9)では，流れの三次元性 の影響は水深が浅く地形が複雑となる湾域や陸域での津 波氾濫流では重要となるが, 水深の深い場所ではほとん ど現れなかった。 このことから，本研究では，断層モデ 儿を含む広域の津波伝播解析と追波湾, 北上川, 汇濫域 を含む詳細領域の津波遡上・汇濫流解析の二つのステッ プに分けて解析を行う.

広域の津波伝播解析において, 初期水位は東北大学乇 デル(version1.2) $)^{7}$ と藤井・佐竹モデル(version4.2) ${ }^{8}$ のそそれ ぞれの断層モデルから， Okada ${ }^{10)}$ 方法で与える. 用い る解析法は平面二次元解析法であり, メッシュスケール 比1/3(1350～50m)の1wayネスティング手法9)を適用する （図-1参照）。

詳細領域の津波遡上・汇濫流解析においては，広域の

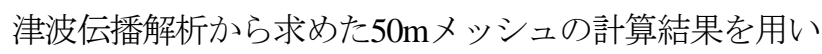
て, 湾域の水位，流速の時空間分布を与える（図-2参 照）。詳細領域の解析法は非静水圧準三次元津波解析法

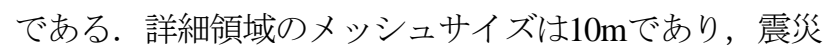
前の地形に対して地形全体一様に $70 \mathrm{~cm}$ の地盤沈下を考 慮して地形データを作成している．津波来襲前の北上川 では干潮直後の上げ潮の時間であり，水面勾配がほとん 


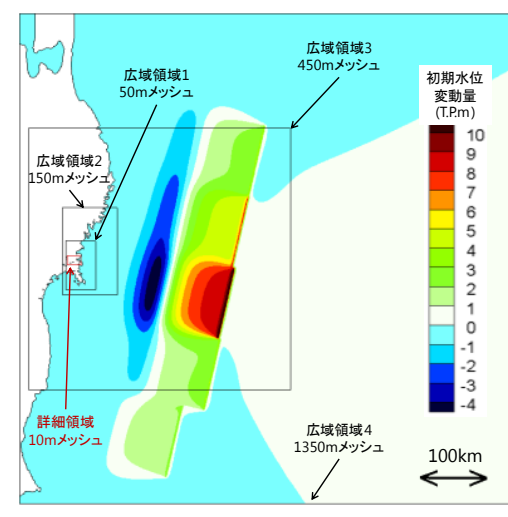

図-1 広域計算領域（東北大学モデルによる初期水位）

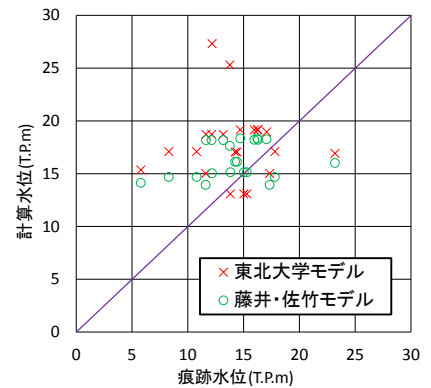

図-3 湾内での計算水位と痕跡水位の比較

ど水平であったと考えられる．津波来襲時の河川の流況 を再現するのは困難であるため，本解析では地震発生時 の河道内, 湾内の初期水位は, T.P.0.0mに断層モデル

（東北大学モデル）による沈下量を与えることで考慮し た。しかし，後述の観測所の水位波形図からわかるよう に実測值と計算初期水位には差異が生じており，初期水 位の与え方については今後も検討が必要である．北上川 の実測水位データより，約49km地点まで津波の遡上が 確認されているが，大堰付近の痕跡水位より，大堰下流 では反射による水位上昇，大堰上流では津波波高の大幅 な減衰が確認されている．このことから，本解析では津 波波高が大きい北上大堰より下流に主眼を置き，北上大 堰を完全反射条件として取り扱い，その上流には津波が 遡上しない条件を設定している，底面粗度は，手引き11) に示されている值を参考に水域は $n=0.025$ とした. 高水 敷は植生が繁茂していることから $n=0.028$ ，堤内地は全 て一様に $n=0.030$ とし，これらのマニングの粗度係数を Manning-Stricklerの式から相当粗度 $k_{s}$ に換算し与えた。

\section{（2）断層モデルの比較}

断層モデルによる津波遡上の再現精度の差について検 討寸る．図-3は広域計算における湾内での計算水位と痕 跡水位の比較である. 痕跡水位は東北地方太平洋沖地震 津波合同調査グループによる調査結果 ${ }^{12}$ である. どちら の断層モデルでの計算結果も痕跡水位に比べ水位を大き く計算している．これは，解析において湾内の複雑な地 形や樹木によるエネルギー減衰の評価が不十分であるこ とが考えられる. 今次津波のような大規模な津波では, 湾内においても強い流れが発生しており, 湾内の抵抗評

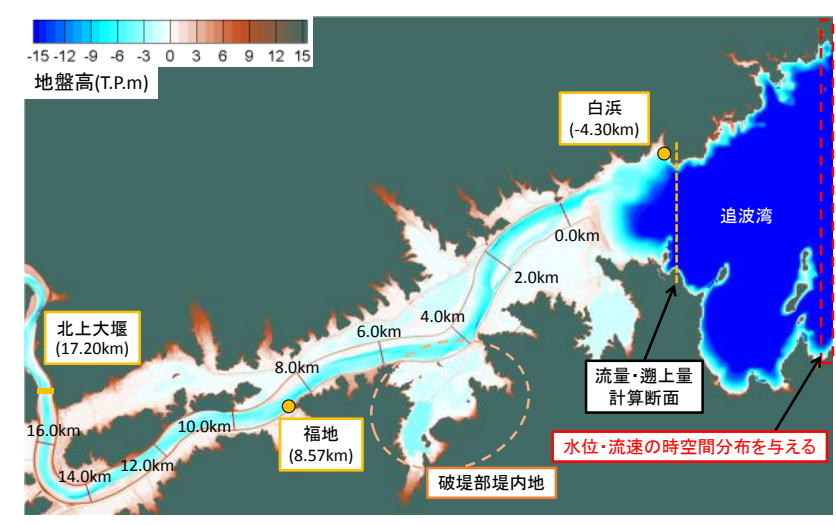

図-2 詳細計算領域

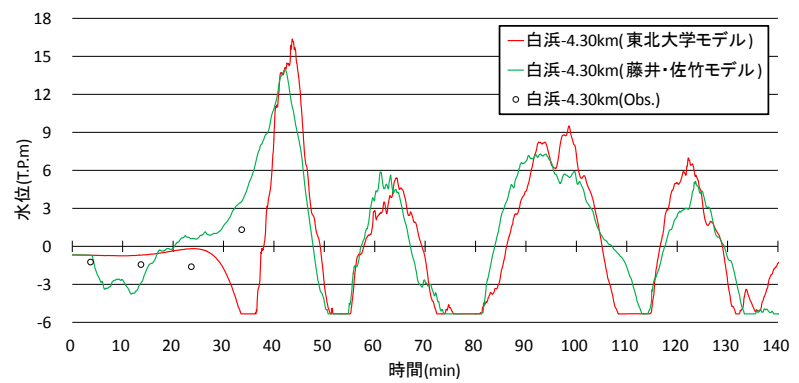

図-4 白浜(-4.30km)での水位波形

価法等については今後さらに検討する必要がある。二つ の計算結果を比較すると, 東北大学モデルの計算結果で は水位を高く計算している点が二つあるが，それ以外の 点では，その差は大きくないように見える. 図-4は，白 浜(-4.30km)での水位波形の比較である．湾内の白浜では， 実測データは10min間隔データであり，激しい津波に よって津波到達とともに久測しているため, 断層モデル の優劣は議論できないが，東北大学モデルでの計算結果 は，大きく水位が低下してから第一波目が到達するのに 対し, 藤井・佐竹モデルでは, 緩やかな水位上昇の後に 第一波目が到達する．各波の峰を藤井・佐竹モデルが低 く計算しており，各波の到達時間にも差があるものの， 第一波目到達以降の全体的な波形については同様である と言える. 図-5は，図-2に示寸湾内断面での流量・遡上 量ハイドログラフである.ここで河道遡上方向の流量を 正としている. 白浜での水位波形には大きな差は見られ なかったものの，(a)を見ると，第一波目の流量波形は 大きく異なり，ピーク流量においても大きな差が生じて いる. (b) は河川への遡上量の時間変化であり，(a) で示 した流量を時間積分したものである. 第一波目の流量波 形の違いにより, 遡上量の差が約-5,000万 $\mathrm{m}^{3}$ から約 $+4,000$ 万 $\mathrm{m}^{3}$ と急激に変化しており, この第一波目の違い は大きなものであると考えられる。しかし，(a)からわ かるように，第二波目以降の両者の全体的な流量波形の 違いは大きくないことから，第二波目以降の遡上量の差 は大きくない. 図-6は, 福地 $(8.57 \mathrm{~km})$ での水位波形の比 較である. 両断層モデルでの計算結果を比べると, 藤 井・佐竹モデルでは, 河川への津波遡上量による差から 第一波の津波波高が1m近く低下しており，断層モデル 


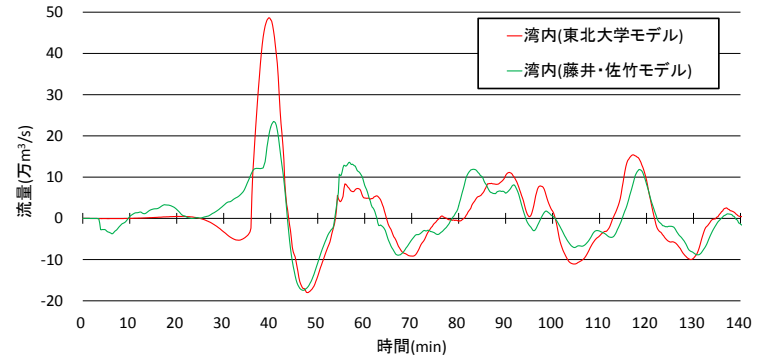

（a）流量

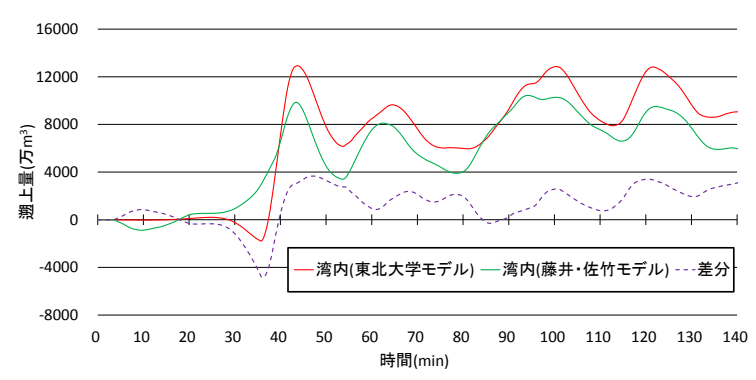

(b) 遡上量と差分

図-5＼cjkstart湾内(図-2 参照)での流量 ・ 遡上量ハイドログラフ

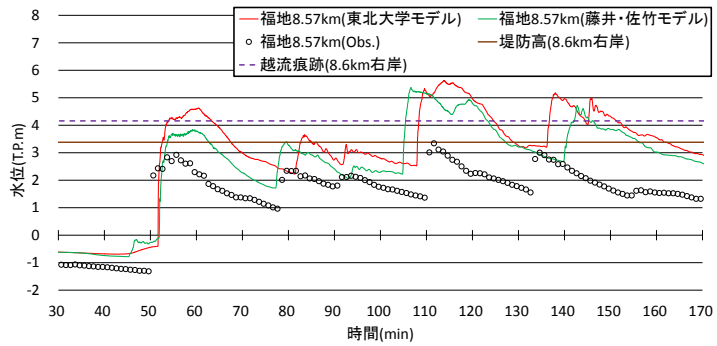

図-6 福地 (8.57km) での水位波形

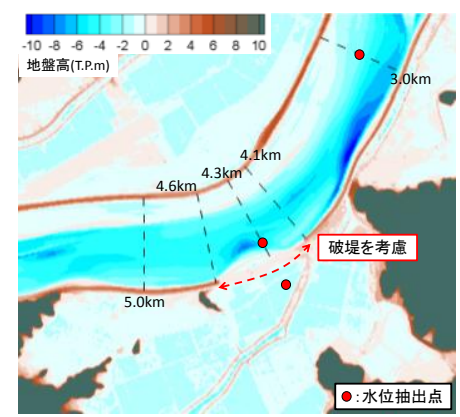

図-7 破堤箇所と水位抽出位置

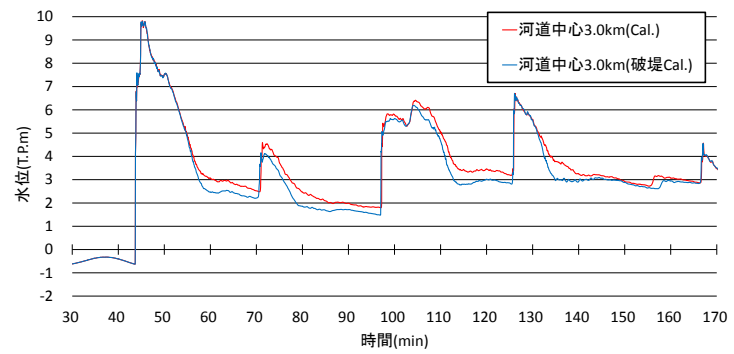

図-8 破堤箇所より下流の河道中心3. 0km (図-7参照) での水位波形

による再現性の差が生じている。また，第二波目以降の 各波の到達時間はやや異なるが，最大水位の差は実測值 との差に比べて小さい. 二つの計算結果と実測值を比べ ると，計算結果は水位を高く計算しており，時間が経過 するにつれて実測值との差が大きくなっている，これは， 計算結果での津波の遡上量が実際より多いと考えられる ことと，計算では北上大堰を通過する津波を無視したこ とにより，河道内の水量が実際より多くなっていること が原因と考えられる。しかし，実測值の詳細な波形の特 徵が再現できていないことから，再現性の向上には，湾 内の解析精度の向上，堰を通過する津波の考慮と合わせ て, 河道地形や堤防，構造物，破堤等の河道条件を適切 に考慮することが重要であると考えられる.

\section{（3）破堤が津波遡上に与える影響}

河道内の津波遡上や汇濫流に及ぼす破堤の効果につい て検討する.まず，本検討での破堤の考慮方法について 示す．実際に津波による大規模な破堤が生じた北上川右 岸 $4.1 \mathrm{~km} \sim 4.6 \mathrm{~km}$ 破堤を考慮した計算を行った. 今回の 検討では簡単のため, 計算初期から破堤が生じた箇所の 堤防を取り除くことで破堤を取り扱った（図一参照）. 堤防を取り除いた箇所の地盤高は，周辺の堤内地の地盤 高よりわずかに高いT.P.+0.5mとした。これは，周辺の 堤内地の地盤高が計算上での初期の河道内水位より低い ことから，津波到達前に堤内地への浸水が生じないよう にしたためである．破堤による地形変化や残存する堤体 の高さ，破堤を生じさせる時間については，今後の検討 課題である. なお，本検討では東北大学モデルの断層モ デルによる計算結果を用いている.

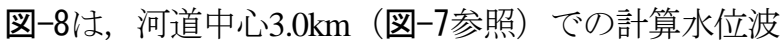
形の比較である．破堤箇所の下流にあたる3.0kmでは， 第一波目でピーク水位を記録することから，ピーク水位 には破堤の影響が表れない.しかし，第一波目の通過後 は破堤により河道内の水量が異なるため, 破堤を考慮し た計算結果の水位が破堤を考慮しない計算に比心，低く なっている．図-9は，破堤箇所より上流の観測所での水 位波形の比較である.（a）の福地 $8.57 \mathrm{~km}$ では，どちらの 計算結果も実測值に比べ，水位を高く計算しているが， 二つの計算結果を比べると，破堤により各波の水位を大 きく減衰させている. (b) の北上大堰下流左岸 $17.20 \mathrm{~km}$ では，計算結果は第一波目と第二波目の到達時間を再現 しているが，後続の波の到達時間や各波の水位の大小関 係を再現できていない。これは，計算では北上大堰を不 透過の壁として取り扱い，堰を通過する津波を無視して いることや堰周辺の詳細な地形が十分考慮されていない ことなどが原因と考えられる. 二つの計算結果を比べる と，（a）と同様に破堤の考慮により，大きな水位低下が 生じていることが確認できる.さらに，破堤の影響に よって各波の到達時間の遅れが，（a）と比較してはっき りと見えるようになっている。図-10には，左岸，右岸 での河道内のピーク水位縦断分布を示す. どちらの計算 結果も痕跡に比べて水位を高く計算しているが，破堤を 考慮した計算結果では破堤部より上流で全体的にピーク 


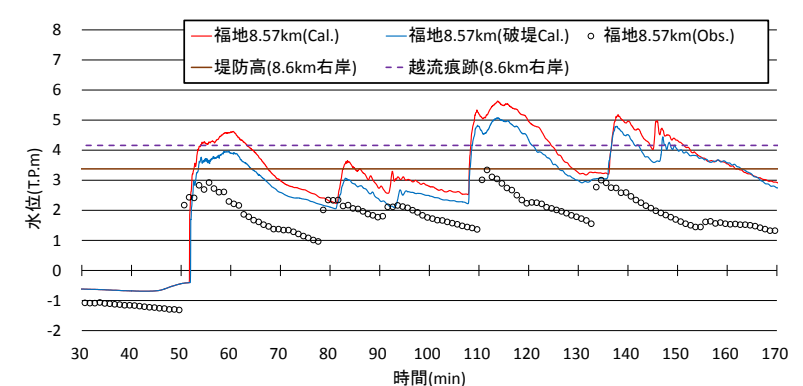

(a) 福地 $(8.57 \mathrm{~km})$

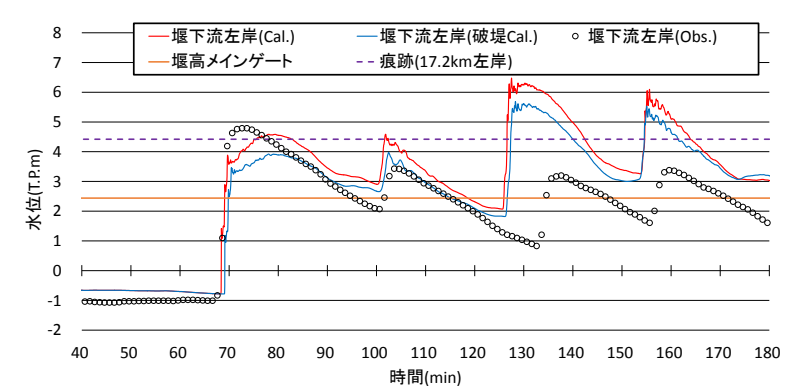

(b) 北上大堰下流左岸 $(17.20 \mathrm{~km})$

図-9＼cjkstart破堤箇所より上流の観測所での水位波形

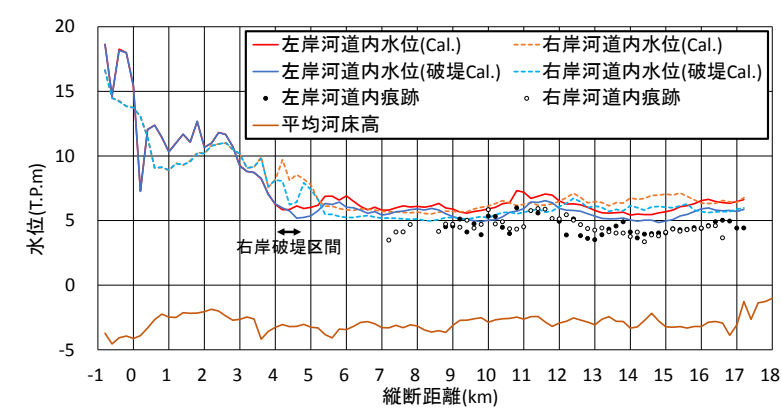

図-10 河道内ピーク水位縱断分布

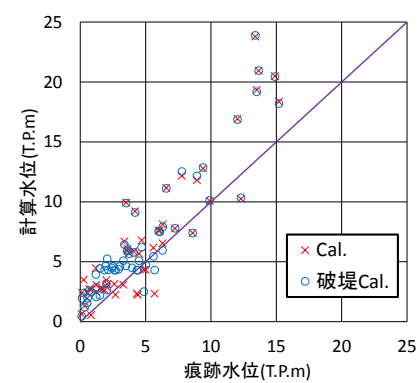

(a) 湾内を除く全体

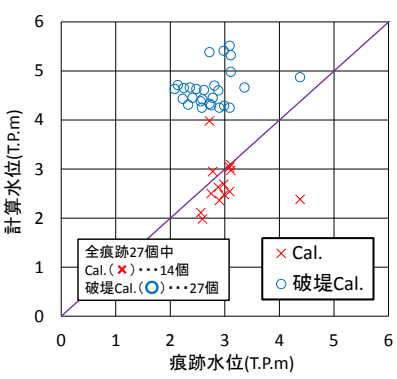

（b）破堤部堤内地(図-2 参照) 図-12 計算水位と汇濫痕跡水位の比較

水位が低下し，実測值に近い水位となっている. 図-8, 図-9からも明らかなように，ピーク水位への破堤の影響 は破堤部の上流河道に限定されており，その下流河道へ の影響はほとんどないことがわかる，図-11は河道 $5.0 \mathrm{~km}$ 断面での流量・遡上量ハイドログラフであり，(b) は(a) の流量を時間積分した遡上量の時間変化である。（a）を 見ると，破堤を考慮することにより，第一波目による ピーク流量が約 $7,000 \mathrm{~m}^{3} / \mathrm{s}$ 低減する. これにより約 300 万 $\mathrm{m}^{3}$ の差が遡上量に生じ, 結果として破堤部より上流の河 道で $1 \mathrm{~m}$ 程度の水位差が発生していることがわかる。図一 12は計算水位と汇濫痕跡水位の比較である。（a）は湾内 を除く全体の比較であり，痕跡水位は東北地方太平洋沖 地震津波合同調査グループによる調査結果 ${ }^{12)}$ である。計 算結果は全体的に水位を高く計算しており，二つの計算 水位の差は高い痕跡水位ではほとんど無いが，約 T.P.0 6mの低い痕跡水位では見られる.これは，破堤を 考慮した計算結果が破堤部堤内地において水位を高く計 算し，破堤区間より上流の堤内地では水位を低く計算し たためである. (b) は破堤部堤内地 (図-2参照) での比 較であり, 痕跡水位は東北地方整備局により計測された ものである．破堤を考慮した計算結果は，全ての痕跡水

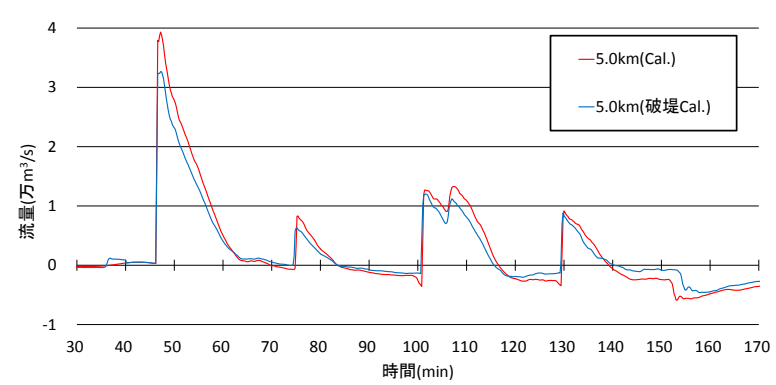

(a) 流量

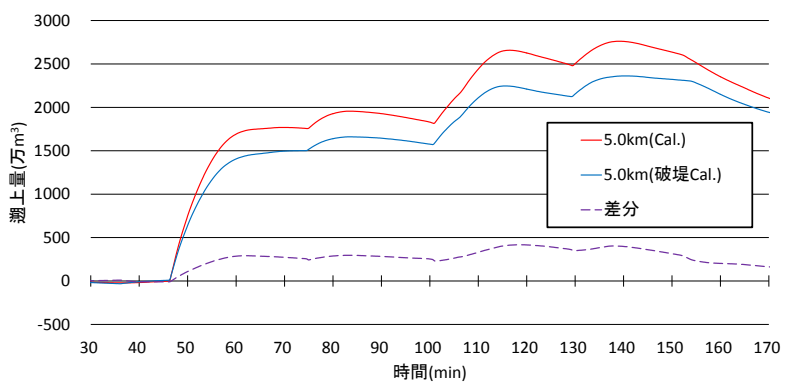

(b) 遡上量と差分

図-11 河道 5.0km 断面での流量・遡上量ハイドログラフ

位に対して水位を高く計算している，一方，破堤を考慮 しない計算結果では，堤防に近い位置での痕跡水位に対 して水位を高く計算しているが，それ以外の点では全体 的に痕跡水位より低く水位を計算している，さらに，痕 跡計測位置に水が到達しない場合，計算上での最大水位 は図中にプロットできず，破堤を考慮しない計算結果に おいて全27個の痕跡のうち, 半数の痕跡位置に汇濫流が 到達せずに14個しかプロットされていない. 河道内の水 位波形や痕跡水位に対して計算結果は水位を高く計算し ていることから，この破堤部堤内地での痕跡水位の再現 には，破堤を考慮することが重要であると言える．図一 13は破堤部付近での計算水位波形の比較である. 水位抽 出位置は図-7に示す通りである. 河道内の水位波形は破 堤の考慮により，水位が大きく低下しているが，全体的 な波形に大きな違いはない. 堤内地の水位波形は破堤を 考慮しない場合，第一波目と第三波目での汇濫流により 水位上昇が生じていることが確認できるものの, 堤内地 の広さに対して越流量が少ないことから, 氾濫流によっ て堤内地の水位が上昇しにくい. このため, 図-12(b)に 示すように痕跡位置に氾濫流が到達しない結果になった と考えられる. 一方, 破堤を考慮した場合には堤内地の 


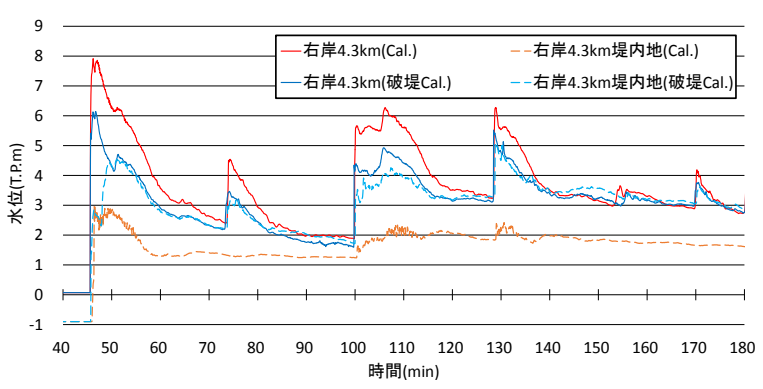

図-13 破堤部付近(図-7参照)での水位波形

水位波形が河道内の水位波形と同様になるほど，多くの 汇濫流が堤内地一と流入していることがわかる。この結 果, 図-12 (b) に示したように, 氾濫痕跡水位よりも高い 計算最大水位の分布になった. これは, 河川に遡上する 津波のボリュームが大きいことも原因の一つと考えられ るが，汇濫痕跡水位の再現は破堤考慮の有無の二つの計 算結果の間にあると考えられるため, 破堤が実際に生じ た時間が第一波目の到達後すぐではなく, それ以降の後 続の波により生じたことも考えられる.

\section{4. 結論}

本研究では，大規模な破堤汇濫を含む広範囲の堤防越 流が生じた北上川を対象として，適切と考えられる解析 法を用い，二つの断層モデルの比較と破堤の考慮から， 今次津波の河川遡上と津波氾濫流解析を行い，様及な現 地観測データを考察した. 以下に得られた結論を示す.

1) 東北大学モデル (version1.2) と藤井・佐竹モデル (version4.2)の二つの断層モデルを用いた今次津波の北 上川の津波遡上再現計算結果を比較し, 東北大学モデ ルが藤井・佐竹モデルに比べ津波の遡上量が多く計算 され，湾内や河道内で水位が高くなることを示した. いずれも全体的に実測值よりも津波の波形が大きく解 析されたことから, 再現性の向上には湾内の解析精度 の向上が重要である.

2) 大規模な破堤が生じた北上川右岸 $4.1 \mathrm{~km} \sim 4.6 \mathrm{~km}$ の破堤 を考慮した計算を行い，破堤無しの計算結果との比較 から, どちらの計算結果も実測值に比べ水位が高く計 算された. しかし，破堤により河道内の縦断ピーク水 位分布や破堤部付近の堤内地の痕跡水位の再現性が改 善され，上流河道では流量が大きく低減し，水位低下 すること，また津波の到達時間が遅れることを示した。 さらに，破堤が生じた時間は第一波目到達後すぐでは なく, それ以降の後続の波により生じた可能性がある ことを明らかにした。

3）上述の検討を行うためには, 痕跡データのみならず, 河道・汇濫域の多点での水位時系列データが取得され ていることが望ましい，そして，実測データと信頼性
の高い解析モデルによる計算結果を相互に検証，考察 することで，破堤などを含めた津波遡上と汇濫の現象 を解明していくことが肝要である.

謝辞 : 本論文で使用した観測所での水位波形, 河道内縦 断痕跡水位, 汇濫痕跡水位は国土交通省東北地方整備局, 国土技術政策総合研究所に提供頂いた。ここに記して謝 意を表す.

\section{参考文献}

1) 松井大生, 内田龍彦, 中村賢人, 服部敦, 福岡捷二: 非静水 圧淮三次元解析法による北上川の津波河川遡上・氾濫流の一 体解析, 土木学会論文集B2(海岸工学), Vol.71, No.2, I _181- I_186, 2015.

2) 内田龍彦, 福岡捷二: 浅水流の仮定を用いない水深積分モデ ルによる底面流速の解析法, 土木学会論文集B1(水工学),

Vol.68, No.4, I_1225- I_1230, 2012.

3) 中村賢人, 森笿年, 鈴木広幸, 服部敦 : 津波遡上の最大水位 に河川流量が与える影響に関する実験, 土木学会年次学術講 演会, 第70回年次学術講演会, Vol.70, pp.303-304, 2015.

4) 赤穂良輔, 石川忠晴 : 平成23年東北地方太平洋沖地震津波に おける利根川下流の津波遡上再現計算, 土木学会論文集 B1(水工学)，Vol.68，No.4， I_1543- I_1548， 2012.

5) 二階堂竜司, 青木伸一, 田村浩敏, 神保正暢, 栗山広宣: 一 般座標系を適用した河川の津波遡上計算〜利根川におおる東 北地方太平洋沖地震津波の再現 , 土木学会論文集B3(海洋 開発)，Vol.70，No.2，I_295-I_300，2014.

6) 小園裕司, 野島和也, 桜庭雅明 : 東京湾内における東北津波 の伝播特性および計算条件の違いによる計算精度の検討, 土 木学会論文集B3(海洋開発), Vol.69,No.2, I_437- I_442,2013.

7) 今村文彦, 越村俊一, 馬㴊幸雄, 大家隆行, 岡田清宏: 東北 地方太平洋沖地震を対象とした津波シミュレーションの実施 東北大学モデル(version1.2), 東北大学大学院工学研究科付属 災害制御研究センター, 2012.

8) Fujii,Y., Satake,K., Sakai,S., Shinohara,M. and Kanazawa,T. : Tsunami source of the 2011 off the pacific coast of Tohoku Earthquake, Earth Planets Space, Vol.63, pp.815-820, 2011.

9) 内田龍彦, 福岡捷二 : 底面流速解析法を用いた津波による構 造物周りの三次元流孔之局所洗掘解析, 土木学会論文集 B2(海岸工学), Vol.69, No.2, I_271- I_275, 2013.

10) Okada, Y. : Surface deformation due to shear and tensile faults in a half-space, Bulletin of the Seismological Society of America, Vol.75, No.4, pp.1135-1154, August 1985.

11）（財）国土技術研究センター: 津波の河川遡上解析の手引 き (案), http://www.jice.or.jp/siryo/t1/pdf/tsunami.pdf (2007). 12)東北地方太平洋沖地震津波合同調查グループ (http://www.coastal.jp/ttjt/)による速報值（2015年2月16日参照）

(2015. 9. 30受付) 